2003

\title{
Misleading Employer Communications and the Securities Fraud Implications of the Employee as Investor
}

Jennifer O'Hare

Follow this and additional works at: https://digitalcommons.law.villanova.edu/vlr

Part of the Securities Law Commons

\section{Recommended Citation}

Jennifer O'Hare, Misleading Employer Communications and the Securities Fraud Implications of the Employee as Investor, 48 Vill. L. Rev. 1217 (2003).

Available at: https://digitalcommons.law.villanova.edu/vlr/vol48/iss4/9

This Symposia is brought to you for free and open access by Villanova University Charles Widger School of Law Digital Repository. It has been accepted for inclusion in Villanova Law Review by an authorized editor of Villanova University Charles Widger School of Law Digital Repository. 


\title{
MISLEADING EMPLOYER COMMUNICATIONS AND THE SECURITIES FRAUD IMPLICATIONS OF THE EMPLOYEE AS INVESTOR
}

\author{
JenNifer O'Hare*
}

\section{INTRODUCTION}

$\mathrm{F}$ OLLOWING the disclosure of Enron's accounting irregularities, the American public was inundated with hundreds of stories describing the disastrous effects of Enron's securities fraud. To me, the saddest stories involved Enron's employees. They lost their investment in Enron. Many of them lost their retirement savings. And they all lost their jobs. They also lost their trust in corporate management. The same sad stories were repeated over and over again. Employees were urged to invest in Enron stock. When the stock price started to fall and when concerns about possible accounting irregularities were raised, management called employee meetings and reassured their employees that all was well. Relying on these assurances, employee investors held on to their Enron stock, even when-in retrospect-it appeared foolish to do so. ${ }^{1}$

When the Enron fact pattern is carefully examined, it becomes clear that employee investors are particularly vulnerable to securities fraud committed by company management. Company management can capitalize on the employment relationship and communicate directly with their employees. These employer communications may be misleading. And although employer communications often encourage employees to invest in company stock, they are left largely unregulated by the federal securities laws.

This Article begins by reviewing the employee investor phenomenon. In Part II, I observe that employers typically encourage company investment by their employees, and employees generally respond by heavily in-

* Professor of Law, Villanova University School of Law; B.S.E., The Wharton School of the University of Pennsylvania; J.D., The George Washington School of Law. I gratefully acknowledge that research for this Article was supported by a summer stipend from the Villanova University School of Law.

1. Consider the following interchange between a television journalist and an Enron employee, which occurred shortly after Enron's accounting irregularities were disclosed:

CBS Anchor Julie Chen: Did you think of bailing out or were you assured

that your money was safe?

Enron employee: We were assured that our money was safe.

Ms. Chen: How so?

Enron employee: Because we trusted Enron. They kept telling us that the

stock was gonna go back up.

Ms. Chen: Who was saying all this to you, Tom? . .

Enron employee: Corporate management.

The Early Show (CBS television broadcast, Dec. 11, 2001). 
vesting in company securities. Part III of this Article continues by highlighting powerful ways companies can communicate with their employee investors-through such media as employee newsletters, employee meetings and employer e-mails. I show that these employer communications are often promotional, purposefully stimulating employee investment in the company.

In Part IV, I argue that employee investors are particularly vulnerable to securities fraud committed by their employer. First, I demonstrate that employer communications pose a unique risk of misleading employee investors, primarily because employer communications are secret in nature. I then show that employee investors are more likely to believe misleading employer communications because of the natural tendency of employees to trust the senior management of their employer. Finally, I point out that employee investors suffer disproportionately when misleading employer communications are made, because employees tend to invest so heavily in company stock.

In Part V of this Article, I demonstrate that the anti-fraud provisions of the federal securities laws do not adequately address the vulnerability of employee investors. Most of the anti-fraud provisions are simply not applicable to misleading employer communications. Moreover, because employer communications are not publicly made, securities fraud actions are unlikely to be brought, either by the Securities and Exchange Commission (SEC) or by private plaintiffs. Furthermore, many misleading employer communications go unpunished under the federal securities laws because employee investors who have been fraudulently encouraged to hold company securities do not have standing to sue under Rule $10 \mathrm{~b}-5$.

In Part VI, I propose that certain types of employer communications should be disclosed to the SEC. If companies are required to disclose employer communications to the SEC, the employer communications would be subjected to critical scrutiny by outsiders and to potential securities fraud liability, making it less likely that employers will make misleading statements to their employees. Thus, I call upon the SEC to promulgate a rule that will require public companies to disclose all employer communications that (1) are widely disseminated to company employees, and (2) are reasonably likely to cause employees to purchase company stock or to refrain from selling company stock. If adopted, such a rule would hopefully reduce the number of sad stories told by employees in the future.

\section{The Employee Investor Phenomenon}

\section{A. Employers Encourage Employee Investment}

Employee investment has become increasingly important to corporations. Many public companies encourage their employees to purchase 
common stock. Several reasons are typically cited. ${ }^{2}$ First, employee investment is commonly thought to increase worker productivity. ${ }^{3}$ The conventional wisdom is that employees who own company stock have an incentive to work harder, leading to improved company performance and higher stock prices. In addition, company managers may view employee investors as shareholders who will be pro-management. By keeping stock in friendly hands, employee investment has an entrenchment effect on management. Finally, compensating employees through stock awards or by stock options may provide attractive tax or other benefits to the company.

To encourage employee investment, most public companies offer certain employee benefit plans which provide incentives for employees to purchase company stock. ${ }^{4}$ Two of the most popular employee benefit plans are employee stock ownership plans (ESOPs) and $401(\mathrm{k})$ plans. An ESOP is an employee benefit plan in the form of a trust that permits a company to make tax-deductible contributions to the ESOP to purchase company stock, or to simply make tax-deductible contributions of its stock to the ESOP. ${ }^{5}$ The company stock is then allocated to individual employees through some pre-determined formula such as salary or years of service. The employees participating in the ESOP do not own the stock immediately; rather, it is typically subject to a five year vesting requirement. After vesting, the employee receives his company stock only after he leaves employment, dies or becomes disabled.

A $401(\mathrm{k})$ plan is an employee benefit plan that permits employees to deduct part of their pay on a pre-tax basis and place it in an investment fund set up by the company. ${ }^{6}$ In a $401(\mathrm{k})$ plan, employees are required to have several investment choices and are free to allocate their investments in different ways. These investment options may be managed by the company, but are often managed by an outside firm such as Fidelity Investments or Vanguard. Most $401(\mathrm{k})$ plans include a company stock fund-

2. There is substantial literature addressing the perceived benefits of employee ownership of company stock. See, e.g., Enron and Beyond: Enhancing Worker Retirement Security; Hearings Before the House Subcomm. on Employer-Employee Relations, House Comm. on Education and the Workforce, 107th Cong. 32 (Feb. 13, 2002) (testimony of Douglas Kruse, Professor, Rutgers University); Olivia S. Mitchell \&c Stephen P. Utkas, The Role of Company Stock in Defined Contribution Plans, Pension Res. Council Working Paper 2002-4, at 1421; Susan J. Stabile, Pension Plan Investments in Employer Securities: More Is Not Always Better, 15 YALE J. on REG. 61, $73-77$ (1998); see also The National Center for Employee Ownership, A Comprehensive Overview of Employee Ownership (visited Dec. 7, 2002) at http://www.nceo.org/library/ overview.html.

3. See Stabile, supra note 2, at 73.

4. The federal securities laws define "employee benefit plan" as "any written purchase, savings, option, bonus, appreciation, profit sharing, thrift, incentive, pension or similar plan or written compensation contract solely for employees, directors, general partners, trustees (where the registrant is a business trust), officers, or consultants or advisors." Securities Act of 1933 Rule 405, 17 C.F.R. $\S 230.405$ (2002).

5. See I.R.C. $\$ 409$ (a) (2) (2002).

6. See I.R.C. $\$ 401(\mathrm{k})(2002)$. 
an investment vehicle consisting entirely of company stock-as an investment option, which permits employees to allocate some or all of their contributions to company stock. ${ }^{7}$ In addition, most $401(\mathrm{k})$ plans provide that the company will match employee contributions, often in company stock contributed to the company's ESOP. Unlike an ESOP, in a 401(k) plan the employee does not actually own the company stock; instead, he owns an interest in the $401(\mathrm{k})$ plan, which may consist largely of company stock. ${ }^{8}$

\section{B. Employees Tend to Invest Heavily in Company Stock}

Employees tend to invest heavily in company stock, often through their 401(k) plans. For example, one study has estimated that of the twenty-three million people who have access to company stock through their defined contribution plans, eleven-million employees hold more than twenty percent of their assets in company stock. And 5.3 million employees are estimated to hold more than sixty percent of their assets in company stock. ${ }^{9}$ Such high concentration levels are widely seen as dangerous. Financial planners commonly advise investors to have no more than ten percent of their holdings in one company. ${ }^{10}$ A diversification strategy is even more important for employee investors; if their employer suffers an economic downturn, employees could lose their investments and their jobs. ${ }^{11}$

These concentration levels are also reflected in the holdings of defined contribution plans. When companies allow employees to invest in company stock, a significant proportion of the company's plan assets are in company stock. For example, a study conducted by the Congressional Research Service indicated that company stock comprised thirty-eight percent of the assets held by the defined contribution plans of large corpora-

7. Moreover, large plans-those with more than 5000 employees-are even more likely to have a company stock option in their $401(\mathrm{k})$ plans. See Jack L. VanDerhei, Company Stock in 401(k) Plans: Results of a Survey of ISCEBS Members, Employee Benefit Res. Inst. Special Rep. 4 (Jan. 31, 2002).

8. An interest in a contributory $401(\mathrm{k})$ plan is a "security" for purposes of the federal securities laws. See Int'l Bhd. of Teamsters v. Daniel, 439 U.S. 551, 570 (1979) (holding that interests in compulsory non-contributory pension plan are not securities for purposes of federal securities laws). Similarly, an interest in a voluntary ESOP constitutes a security. See Uselton v. Commercial Lovelace Motor Freight, Inc., 940 F.2d 564, 572-79 (10th Cir. 1991).

9. See Mitchell \& Utkas, supra note 2, at 11; see also VanDerhei, supra note 7, at 4 (highlighting that in plans permitting employees to invest in employer stock, $42 \%$ of employees have between $10-50 \%$ of their holdings in employer stock and $18 \%$ of employees have more than $50 \%$ of their holdings in employer stock).

10. See, e.g., Kathy M. Kristof, 401(k) Sticker Shock Can Be a Wake-up Call, L.A. Times, Jul. 21, 2002, at $\mathrm{C}-1$ (stating that "the rough rule of thumb is that you shouldn't have more than 5\%-10\% of your assets in your own company's stock").

11. See, e.g., Sharon Epperson, Don't Bet It All on Your Employer: The Plunge of Enron Stock Serves as a Warning That Workers Should Not Invest Too Much in Their Company, Time, Dec. 3, 2001, at 79 (discussing why employees should follow diversification investment strategy). 
tions. ${ }^{12}$ Other studies also support the conclusion that defined contribution plans tend to have high concentrations of company stock. ${ }^{13}$ At certain companies, the percentage of plan ownership of company stock is even higher than the numbers indicated by the Congressional Research Service study. ${ }^{14}$ For example, more than sixty percent of the Enron 401 (k) plan was invested in Enron stock. ${ }^{15}$

Why do employees tend to invest so heavily in company stock? There are a number of explanations. ${ }^{16}$ First, employees may simply believe that employer stock is a superior investment. ${ }^{17}$ Employees may also invest out of a sense of loyalty to their employer. ${ }^{18}$ There may also be peer pressure to invest in company stock. ${ }^{19}$ Finally, as discussed below, employees are often encouraged by senior management to invest in the company. ${ }^{20}$

High levels of concentration may occur because employees choose to invest in employer stock. However, concentrated employer stock holdings are also a result of employer matching programs. ${ }^{21}$ To encourage employee saving, companies often match employee contributions to their 401 (k) plans. Sometimes, the employer matches in cash, and the employee can then allocate the money as he pleases. Often, however, the

12. See Patrick J. Purcell, Employer Stock in Retirement Plans: Investment Risk and Retirement Secutity, Cong. Research Serv. Rep. For Cong. RL.31507, at 10 (July 12, 2002).

13. For example, a study conducted by the Employee Benefit Research Institute (EBRI) found that where company stock is offered either as an employer match or an investment option, $32 \%$ of the plan assets were in company stock. See VanDerhei, supra note 7, at 2. For a discussion of other studies, see Purcell, supra note 12 , at 8-12.

14. For example, more than $90 \%$ of the Procter \& Gamble defined contribution plan was invested in company stock. See Steven Greenhouse, Response to 401 $(k)$ Proposals Follows Party Lines, N.Y. Times, Feb. 2, 2002, at C-1; see also id. (listing other plans with high concentrations of company stock).

15. See Patrick J. Purcell, The Enron Bankruptcy and Employer Stock in Retirement Plans, Cong. Research Serv. Rep. for Cong. RS21115, at 3 (Jan. 22, 2002) (discussing concentration levels of employer stock in 401 (k) plans).

16. The literature in this area is substantial. For a good overview, see Susan J. Stabile, Another Look at 401(k) Plan Investments in Employer Securities, 35 J. Marshall L. Rev. 539, 547-52 (2002).

17. And, in fact, behavioral studies indicate that employees may have an optimistic bias towards their company and its securities. See Susan J. Stabile, The Behavior of Defined Contribution Plan Participants, 77 N.Y.U. L. REv. 71, 91 (2002).

18. See id.

19. See Daniel Altman, Bush Promises a Look at Employee Risks, but Experts Say Solutions Won't Be Easy, N.Y. Times, Jan. 11, 2002, at C-1 (noting that "some employees felt social pressures to put even their own money into company stock"); Steven Greenhouse, Plan to Put Limits on 401(k) Holdings Draws Fire, N.Y. Times, Feb. 9, 2002, at $\mathrm{C}-1$ (noting that "[a]t some companies, not to hold large amounts of company stock is viewed as disloyalty").

20. See Greenhouse, supra note 19, at C-1 (revealing that "employers press employees to load up on company stock in their $401(\mathrm{k})$ plans and elsewhere"). For further discussion of how Enron managers encouraged employees to purchase and hold company stock, see infra Part III.

21. See Mitchell \& Utkus, supra note 2, at 11-13. 
employer match is made in company stock, leading to higher concentrations of company stock in $401(\mathrm{k})$ plans. ${ }^{22}$ Many plans also restrict employees from selling company stock contributed by the employer for long periods of time, thereby significantly increasing concentration levels. ${ }^{23}$

\section{The Significance of Employer Communications}

The growth of employee investors has resulted in a powerful and distinct method for a company to communicate with an identified group of investors. Companies can certainly communicate with their employee investors through public documents and press releases, which are also made to non-employee investors. By capitalizing on the employer-employee relationship, however, companies can communicate with employee investors in other ways such as through employee newsletters and publications, employee meetings, inter-office memoranda and e-mails, and employee online chats. Some employer communications may address issues that relate only to employment, such as employment benefits information, salary and promotion policies, and sexual harassment policies. Other employer communications may address more general information about the company, its prospects, and its stock price.

Employer communications that address more general information about the company may be made for a variety of purposes. They may be made to respond to employee concerns about job security, such as when a financially distressed company reassures its employees that the company will remain in business. Or they may be made to educate employees and improve morale, such as when a company facing criticism from journalists, or facing investigation by a government agency, wants to give its side of the story to its employees. And, finally, they may be made to stimulate employee investment in the company, such as when a company tells its employees that its stock price will improve or that its stock is undervalued.

The promotional nature of employer communications is demonstrated by the type of statements made by Enron management to Enron employees before the accounting irregularities were disclosed to the public. Sometimes the promotional nature of the statements made by Enron management addressed company performance. For example, at an Enron employee meeting, Kenneth Lay, the Chairman of Enron, told employees:

[a]nd let me say we're well into the fourth quarter now, and the fourth quarter's looking good. We'll end up the year in good shape, will certainly meet the street's expectations and again it

22. See VanDerhei, supra note 7 , at 5 (finding that $43 \%$ of companies having company stock investment option in their $401(\mathrm{k})$ plans required employer matching contributions to be made in company stock).

23. See id. (finding that $60 \%$ of plans prohibit employees from selling employer stock until specified age and/or service requirement is met). 
will be a great year for Enron and Enron's shareholders. And, of course, all of you in this room are also Enron shareholders. ${ }^{24}$

In addition to promotional communications addressing company performance, Enron management also made a series of promotional statements concerning the price of the company's stock. In its communications with employees, management often made predictions about where the price would go in the future, and that place was always up. For example, in a meeting with employees, Mr. Lay told employees that "we're pleased with the growth that we've had in the stock price over the last 18 months or so, but, indeed we think, in fact, it can go quite a bit further, and not long term, but near term." ${ }^{25}$ He continued, "that we'll see this stock price quite a bit higher even over the next year to 18 months." ${ }^{26}$ Management also made specific predictions as to stock price, telling employees, for example, "that think even over the next several months that there's a good chance that the stock price could be up as much as fifty percent, and I think there's no reason to think that over the next two years that we can't double it again, at least double it." ${ }^{27}$

In its employer communications, Enron management also compared Enron stock favorably to other stocks and investment opportunities. For example, at one employee meeting, Mr. Lay observed that "our shareholders got a total return of over 600 percent, about a sevenfold increase in their investment during this decade. And that's one-and-a-half times the return for the S\&P 500 in what is now viewed as the largest or strongest bull market in our history." 28 When the price of Enron stock fell, Enron management continually reassured employees that its stock was still a good buy. For example, in an employee chat session held just a few months before Enron declared bankruptcy, Mr. Lay told employees that "Enron stock is an incredible bargain at current prices and we will look back a couple of years from now and see the great opportunity that we currently have." 29

All of these promotional statements were clearly intended to encourage employees to keep investing in Enron. However, if some employees failed to understand the implied message, Enron management also

24. See First Consolidated and Amended Complaint I 248, Tittle v. Enron Corp., No. H 01-3913, (S.D. Tex. Civ., filed Apr. 8, 2002) [hereinafter Enron Complaint].

25. Id. II 247.

26. Id. I 247.

27. Id. I 249 (statement of Joseph Sutton, Vice-Chairman of Enron).

28. Id. I 246. In another employees' meeting, Mr. Lay told employees that "[s]tarting early in 1999 and going through September of this year...., Enron Corp. shareholders have had over a 1,400-percent or over 15-fold, if you want to put it that way, increase in their investment over that period of time. Obviously, well over three times what the average has been for the S\&P 500. They're in a really strong bull market, the S\&P 500...."Id. I 257.

29. Id. I 269. 
sent an express message. Thus, for example, at an employees meeting, an employee asked, "Should we invest all of our 401(k) in Enron stock?" Management's response, "absolutely," and added that "there's no reason to think that we couldn't see a $\$ 15, \$ 20, \$ 25$ increase in stock price over the next 12 months or so." 30

\section{Employee Investors Are Particularly Vulnerable to Securities Fraud}

Employer communications permit companies to communicate with an important segment of their investors-company employees. These employer communications can help employee investors make informed decisions about purchasing company stock, so long as they are accurate. However, they can also mislead employee investors. In fact, employer communications pose a unique risk of misleading employee investors. This danger is exacerbated because, given employees' trust in company management, employees are more likely to believe the misleading employer communications. ${ }^{31}$ Further, employee investors suffer disproportionately from misleading employer communications because they often invest so heavily in company stock. Thus, employee investors are particularly vulnerable to securities fraud.

\section{A. Employer Communications Pose a Unique Risk of Misleading Employee Investors}

Employer communications pose a unique risk of misleading employee investors into purchasing or holding company stock. This danger can be traced to the non-public, or secret, nature of employer communications, which increases the risk that the employer communication will be misleading. As discussed above, companies communicate with their employees on an ongoing basis, through employee newsletters and publications, employee meetings, inter-office memoranda and e-mails, and employee on-line chats. ${ }^{32}$ By definition, the communications made to employees are not disclosed to non-employee investors. They are not public, and they are not required to be filed with the SEC. ${ }^{33}$ These communica-

30. Id. I 250. These statements were made by Cindy $\mathrm{K}$. Olson, an Enron Vice President and a fiduciary of Enron's $401(\mathrm{k})$ plan. IV.B.

31. For discussion of employee trust of company management, see infra Part Part III.

32. For discussion of the significance of employer communications, see supra

33. Employer communications do not have to be filed under the selective disclosure rules of Regulation FD. See 17 C.F.R. $\$ 243.100$ (2002). In general, Regulation FD requires companies to make public disclosure of material non-public information that has been selectively disclosed to others. However, the selective disclosure rules are triggered only when the company makes a disclosure "to any person outside the issuer." See id. \$243.100(b)(1). Disclosures to a company's own employees are not considered as "outside the issuer." See Selective Disclosure and Insider Trading, Securities Act Release No. 33-7787, [1999-2000 Transfer 
tions are-for all intents and purposes-secret. Thus, employer communications are not subject to the usual regulatory forces that tend to discourage corporate fraud. For example, analysts and journalists cannot question the information contained in employer communications. Healthy skepticism by market professionals helps keep companies honest. If no effective challenge to the information exists, there is an increased risk that the employer communication may be misleading.

Similarly, employer communications are more likely to be misleading because the disciplining effect created by the prospect of a securities fraud action is missing. The possibility of a securities fraud action helps deter a company from making misleading statements. Conversely, if a securities fraud action is unlikely, a company may be less careful to ensure the accuracy of its disclosures. Because employer communications are secret, a securities fraud action for a misleading employer communication is not very likely. Attorneys specializing in securities class actions, who may regularly review press releases for misleading corporate disclosures, generally will never see the employer communication and thus will not have the opportunity to bring a securities fraud action if the employer communication was misleading. The secrecy also effectively prevents the SEC from bringing an enforcement action against a company for misleading employer communications. If companies realize that employer communications are basically insulated from liability under the federal securities laws, they may be more likely to make misleading disclosures to their employees. At the very least, companies may be careless about ensuring the accuracy of their employer communications.

\section{B. Employees Are More Likely to Believe Misleading Employer Communications}

Obviously, not all employer communications are false or misleading. But when misleading employer communications are made, employees are particularly vulnerable because they have a natural tendency to trust their employer. ${ }^{34}$ In other words, employees are more likely to believe fraudulent employer communications. This vulnerability is demonstrated by Enron management's statements to employees prior to disclosing the company's accounting problems.

As we all know, the Enron debacle was caused in part by significant accounting irregularities. Even before Enron disclosed the full extent of its problems, however, there were persistent rumors about questionable

Binder] Fed. Sec. L. Rep. (CCH) I 86,228, at 82,846 (Dec. 20, 1999) (stating that Regulation FD "would not apply to communications of confidential information by officials and employees of issuers to each other"). Thus, Regulation FD does not require companies to file employer communications with the SEC, even if they contain material non-public information.

34. The impact of trust on corporate law has just begun to be addressed by legal scholars. See generally Margaret M. Blair \& Lynn A. Stout, Trust, Trustworthiness, and the Behavioral Foundation of Corporate Law, 149 U. PA. L. Rev. 1735 (2001) (using trust concepts to explain corporate fiduciary duties). 
accounting practices at Enron. These rumors were known to Enron employees, and were consistently denied by Enron management. For example, after a critical article about Enron appeared in The Wall Street Journal, Jeffrey Skilling, Enron's Chief Executive Officer, told Enron employees, "So I think the entire article was just, you know, it was just one of these things that gets dredged up every couple of years. It has absolutely no merit, no substance. Our accounting policies are not only appropriate, in my opinion, they're conservatively executed. So we're in a strong position from an accounting basis." 35 On several occasions, employees specifically asked Enron management about its accounting practices and rumored irregularities. Each time, management denied any problems, characterizing these concerns as "unfounded rumors." 36 For example, on September 26, 2001, shortly before Enron disclosed its accounting irregularities, an employee posed the following question to Kenneth Lay:

Mr. Lay-Enron has been aggressive in the use of SPVs [special purpose vehicles] collateralizing future cash flows for the sake of present earnings. I couldn't help but notice our auditor, Arthur Andersen of Houston, recently admitted guilt and paid the largest fine ever for criminal falsifications related to SPVs on behalf of another large Houston corporation. You are a man of integrity, so my "question" is a chance for you to reassure us we have no such problems here at Enron. ${ }^{37}$

Mr. Lay responded:

To begin with, I can assure you that I or the Board of Directors would not approve the use of SPVs or other types of financial vehicles unless we were convinced both by all of our internal offices as well as our external auditor and counsel, that they were legal and totally appropriate. ${ }^{38}$

As demonstrated by the phrasing of the employee's question, this employee believed that his employer would give him the full and honest truth. Even with all of the available conflicting evidence-and by this point in time, the rumors of accounting improprieties at Enron had

35. See Enron Complaint, supra note 24, I 260. Similarly, after a negative article appeared in Fortune Magazine, Mr. Lay told employees that "[ $t]$ he entire reason that this analysis was done by 'Fortune Magazine' is because 'Business Week' had a favorable article about Enron the week before. And there is this competition that the news magazines have, where if one says something good, the other has to come and find something bad." See id. \ 263. He concluded by reassuring employees that "the criticism . . . is kind of ridiculous." See id.

36. See id. II $269 \& 271$. Management also urged employees not to repeat these rumors, pointing out that " $[t]$ o the extent that our employees begin repeating those rumors and spreading those rumors to other employees as well as family members and friends outside the company, it gives them a level of credibility that they do not deserve. And, thus damages the stock price." See id. I 269.

37. Id.

38. Id. 
reached a dull roar-he still trusted this person and, presumably, believed Kenneth Lay's statements denying any accounting irregularities. Why?

The answer must be that an employee is particularly likely to trust his employer. This conclusion appears to be intuitive. Even without any understanding of social psychology or organizational behavior, most of us would agree that an employee typically holds the senior management of his employer in high esteem. The employee is conditioned to follow senior managers. The employee's paycheck is signed by senior managers. In effect, employees may view senior managers as benevolent dictators, who have been entrusted with running the company and ensuring that the employee has a livelihood. Given that, it is easy to conclude that employees place high levels of trust in senior managers, causing employees to be likely to believe what they are told. ${ }^{39}$

This intuitive feeling is supported by the findings of social psychologists who have explored the important question of why people trust. Not surprisingly, this is a complex question, and different scholars have developed different theories of what causes trust. The literature suggests, however, that a person will trust another person when he perceives that the trusted person possesses certain identified qualities or characteristics. ${ }^{40}$ Although social psychologists have identified a variety of qualities that con-

39. Statements made by Enron employees also provide support for this conclusion. See supra note 1. Similarly, employees testifying before Senate and House committees investigating Enron revealed how their trust in Enron management was abused. For example, a retired Enron employee described to a Senate committee one of Enron's employer communications in which employees were told that Enron's 2000 performance was "simply stunning" and that "[e]very one of our businesses performed beyond our expectations." The employee then testified that "[w]e believed in the story in this publication and it is typical of the type of promotion used by Enron executives." See The Collapse of the Enron Corp.: An Overview of the Enron Collapse; Hearings Before the Senate Comm. on Commerce, Science $\mathcal{E}$ Transportation, 107th Cong. (Dec. 18, 2001) (statement of Charles Prestwood, retired Enron employee).

40. For example, one noted scholar identified nine trust conditions: (1) integrity; (2) motives; (3) consistency of behavior; (4) openness; (5) discreetness; (6) functional competence; (7) interpersonal competence; (8) business sense; and (9) judgment. See J.J. Gabarro, The Development of Trust, Influence and Expectations, in INTERPERSONAL. BEHAVIOR: COMMUNICATION AND UNDERSTANDING IN RELATIONSHIPS 290 (A.G. Athos \& J.J. Gabarro eds., 1978). Another study identified integrity, competence, loyalty, consistency/fairness and openness as contributing towards the establishment of employee trust. See Murray C. Clark \& Roy L. Payne, The Nature and Structure of Workers' Trust in Management, 18 J. ORG. BEHAV. 205, 208 (1997). See also Aneil K. Mishra, Organizational Responses to Crisis: The Centrality of Trust, in Trust in Organizations: Frontiers of Theory and Research 261 (Roderick M. Kramer \& Tom T. Tyler eds., 1996) (identifying manager's competence, openness, concern and reliability as important in creating employee trust). Similarly, the following categories of managerial behavior were found to lead to employee trust: (1) behavioral consistency; (2) behavioral integrity; (3) sharing and delegation of control; (4) communication; and (5) demonstration of concern. See Ellen M. Whitener et al., Managers as Initiators of Trust: An Exchange Relationship Framework for Understanding Managerial Trustworthy Behavior, 23 ACAD. MGMT. REv. 513,516 (1998). 
tribute to one person trusting another, most scholars appear to agree that the following characteristics contribute to trust in a managerial setting: (1) the perceived integrity of the trusted person, (2) the perceived competence of the trusted person, and (3) the perceived openness of the trusted person. In other words, if an employee perceives that management has integrity, is competent, and regularly communicates with employees, the employee is more likely to place his trust in management.

These conditions are often present in the relationship between an employee and senior management. Obviously, different employees may perceive different senior managers to have different levels of integrity, as well as different levels of competence and openness. A review of the employee-senior manager relationship, however, indicates that employees in general are apt to believe that senior managers are people of integrity. Senior managers themselves may even foster this image. For example, senior managers are often very publicly active in charitable work. ${ }^{41}$ Such philanthropy may create a "halo effect" around senior management, leading to a perception that these managers are honest and forthright. In addition, corporations often adopt mission statements and codes of ethics that emphasize honest behavior. ${ }^{42}$ By adopting-and preaching adherence to-these ethical standards, senior managers hold themselves out as people of high integrity, who would not lie to their employees. ${ }^{43}$

In addition, it would appear that employees generally perceive senior managers to be competent. By definition, senior managers have attained the highest levels of responsibility in a corporation, which naturally leads to a perception that these people have the skills required to do their jobs. Otherwise, how would they have obtained such powerful positions?

Finally, as discussed above, senior managers often communicate with employees on a regular basis. ${ }^{44}$ In fact, senior managers seeking to develop and cultivate employee trust may deliberately become more accessible to their employees. Such employer communications and accessibility undoubtedly lead employees to develop perceptions that senior management is operating openly and honestly, leading to employee perception that senior managers are trustworthy.

41. See, e.g., Surveys Document Surge in Volunteering, 18 NONPROFIT WorLd 40 (Jan./Feb. 2000) (stating that 95\% of CEOs of Fortune 500 companies volunteer for at least one nonprofit corporation and $80 \%$ are on five or more nonprofit boards).

42. Enron's ethics handbook provided that "[r]elations with the Company's many publics-customers, stockholders, governments, employees, suppliers, press, and bankers-will be conducted in honesty, candor, and fairness." See Enron Complaint, supra note 24, II 242.

43. At Enron, for example, senior managers "talked about respect and integrity, and passed out paperweights that said so." See Rich Bragg, Enron's Collapse: Workers Feel Pain of Layoffs and Added Sting of Betrayal, N.Y. Times, Jan. 20, 2002, at A1.

44. For a discussion of the significance of employer communications, see supra Part III. 


\section{Employee Investors Suffer Disproportionately from Securities Fraud}

All investors-employees and non-employees-suffer losses if a company commits securities fraud. However, because employee investors tend to invest heavily in employer stock, they suffer disproportionately if their employer defrauds them into purchasing or holding company stock. ${ }^{45}$ Thus, employees are particularly vulnerable to suffering significant losses from misleading employer communications. ${ }^{46}$

\section{The Anti-Fraud Provisions of the Federal. Securities Laws Do Not Adequately Address the Vulnerability of EMPLOYEE INVESTORS}

As demonstrated above, ${ }^{47}$ employee investors are particularly vulnerable to securities fraud in large part because employer communications

45. For a discussion of the tendency of employees to invest in company stock, see supra Part II.B.

46. Following Enron, there were calls to amend the Employee Retirement Income Security Act of 1974 (ERISA), the primary federal statute regulating private pension and retirement plans, to place caps on employee investment in employer stock or to take other steps to prevent excessive employee investment in employer securities such as educating employees about the value of diversification. See Greenhouse, supra note 19, at C-1 (discussing calls for reform made by Senator Jon S. Corzine, Democrat, New Jersey). Because laws that would have the effect of reducing employee investment have so far proved to be quite controversial, Congress has not enacted such legislation. See generally id. (discussing advantages and disadvantages of cap on employee investment).

If Congress decides to place substantive restrictions or limitations on employee investment, the restrictions should not be made via the federal securities laws. The goal of the federal securities laws is to promote informed investment decisions. In other words, the federal securities laws do not seek to dictate investment choices or strategies. Instead, the approach of the federal securities laws is to ensure that investors have adequate information so that they can make their own choices. Therefore, a provision placing restrictions on employee ownership-such as a cap-would be inconsistent with the disclosure philosophy underlying the federal securities laws. On the other hand, it would be entirely consistent with goals of ERISA, which was enacted by Congress to protect the interests of employees in their pensions, thereby helping to ensure that employees would have sufficient savings for retirement. At the time ERISA became law, Congress was concerned with concentrated holdings of employer securities in pension plans. In fact, ERISA already imposes a cap on employer stock in defined benefit plans. See ERISA $\$ 407$ (a), 29 U.S.C. $\$ 1107$ (a) (2000). However, the decision to impose a cap on ownership of employer stock in $401(\mathrm{k})$ plans implicates several competing policy choices that are beyond the scope of this Article. See U.S. Dep't of TrEas., REP. ON Employer Stock IN 401(K) Plans 4-7 (Feb. 28, 2002) (arguíng against mandatory cap because it would interfere with employee's freedom to invest, it would reduce employer matching contributions, and it would negatively impact U.S. trading markets by forcing plans to sell large amounts of employer stock). Therefore, I take no position on whether ERISA should impose such a cap, or impose any provision that would discourage concentrated ownership of employer securities. Instead, I merely conclude that it would be inappropriate for the federal securities laws to impose such restrictions.

47. For discussion of the vulnerability of employee investors to securities fraud, see supra Part IV. 
pose a special risk of misleading employees into purchasing or holding company stock. Unfortunately, the anti-fraud provisions of the federal securities laws do not adequately address this vulnerability. In fact, misleading employer communications fall outside most of the anti-fraud provisions of the federal securities laws. ${ }^{48}$ Thus, defrauded employees go uncompensated for their losses. And, perhaps more importantly, senior management is not deterred from making misleading employer communications.

The federal securities laws set forth several anti-fraud provisions, including Section 11 of the Securities Act of 1933 ("'33 Act"), ${ }^{49}$ Section

48. In addition, liability for many misleading employer communications would also appear to fall outside the scope of ERISA. See Stabile, supra note 16, at 561 (stating that claims that misleading employer communication violated ERISA would "not be easy lawsuits for plaintiffs"). ERISA imposes fiduciary duties on plan fiduciaries. Specifically, Section 404(a)(1) of ERISA requires a plan fiduciary to act "solely in the interest of the participants and beneficiaries" of the plan. See ERISA \$ 404(a) (1), 29 U.S.C. \$1104(a) (1) (2000). It is clear that misrepresentations made by a fiduciary in a fiduciary capacity violate the fiduciary duties imposed by ERISA, subjecting the fiduciary to liability under ERISA. See Varity Corp. v. Howe, 516 U.S. 489, 506-07 (1996). As the Supreme Court reasoned, "lying is inconsistent with the duty of loyalty owed by all fiduciaries and codified in Section 404(a) (1) of ERISA." Id. at 506. However, the law is very unclear as to what types of statements can be attributable to a "fiduciary" while "acting in a fiduciary capacity." For example, a court may well determine that an employer communication made by a company or its management to its employees was not made in a fiduciary capacity, but rather in an employer capacity or in a normal business operations capacity. As a leading commentator noted, "[i]t remains to be seen whether a court will decide that [employer communications urging employees to purchase employer stock] were made in a fiduciary capacity and therefore give rise to ERISA liability." See Stabile, supra note 16, at 563; see also Evan Miller \& Allison Cera, Learming the True Meaning of Fiduciary, the Hard Way, NAT'L L.J., Aug. 12, 2002, at B-8 (concluding that existing case law "does not offer much guidance" on whether misleading employer communications would be actionable under ERISA); Retirement Insecurity: Crisis at Enron; Hearing Before the Senate Comm. on Governmental Affairs, 107th Cong. 128 (Feb. 5, 2002) (statement of Karen W. Ferguson, Director of Pension Rights Center) (asking Senate to amend ERISA to "make plain that company officials, such as Enron CEO Kenneth Lay, who make misleading statements to employees can be sued... . even if the officials claim that they had nothing to do with the running of the plan"). Moreover, the company or its managers making the employer communication may not even be an ERISA fiduciary. See Retirement Insecurity: Crisis at Enron; Hearings Before the Senate Comm. on Governmental Affairs, 107th Cong. 148 (Feb. 5, 2002) (statement of Erik Olsen, Director of AARP) (pointing out that Enron plan participants may be left with no remedy against Enron CEO Kenneth Lay because he might not constitute ERISA "fiduciary").

49. Section 11 provides:

In case any part of the registration statement, when such part became effective, contained an untrue statement of a material fact or omitted to state a material fact required to be stated therein or necessary to make the statements therein not misleading, any person acquiring such security . . . may ... sue-

(1) every person who signed the registration statement;

(2) every person who was a director of . . the issuer at the time of the filing of the part of the registration statement with respect to which his liability is asserted; 
12(a) (2) of the '33 Act, ${ }^{50}$ Section 17 of the ' 33 Act,, 51 Section 18 of the Securities Exchange Act of 1934 ("' 34 Act"), 52 and Rule 10b-5 of the '34 Act. ${ }^{53}$ These anti-fraud provisions-which may adequately serve non-em-

(3) every person who, with his consent, is named in the registration statement as being or about to become a director ... ;

(4) every accountant ... with respect to the statement in such registration statement ..., which purports to have been prepared or certified by him;

(5) every underwriter with respect to such security.

Securities Act of $1933 \$ 11$ (a), 15 U.S.C. $\$ 77 \mathrm{k}$ (a) (2000). For further discussion of Section 11 , see Thomas Lee Hazen, The Law of Securities Regulation $\$ 7.3$ (4th ed. 2002).

50. Section 12(a) (2) provides:

Any person who ... offers or sells a security ... by means of a prospectus or oral communication, which includes an untrue statement of material fact or omits to state a material fact necessary in order to make the statements, in the light of the circumstances under which they were made, not misleading ... shall be liable ... to the person purchasing such security from him, who may sue either at law or in equity in any court of competent jurisdiction, to recover the consideration paid for such security with interest thereon, less the amount of any income received thereon, upon the tender of such security, or for any damages if he no longer owns the security.

Securities Act of $1933 \S 12$ (a) (2), 15 U.S.C. $\$ 771$ (a) (2) (2000). For further discussion of Section 12(a)(2), see HAZEN, supra note 49, § 7.6.

51. Section 17 provides:

It shall be unlawful for any person in the offer or sale of any securities ...

(1) to employ any device, scheme, or artifice to defraud, or

(2) to obtain money or property by means of any untrue statement of a material fact or any omission to state a material fact necessary in order to make the statements made, in light of the circumstances under which they were made, not misleading; or

(3) to engage in any transaction, practice, or course of business which operates or would operate as a fraud or deceit upon the purchaser. Securities Act of $1933 \$ 17$ (a), 15 U.S.C. $\$ 77 q$ (a) (2000). For further discussion of Section 17, see HAZEN, supra note $49, \S 7.11$.

52. Section 18 of the ' 34 Act provides:

Any person who shall make or cause to be made any statement in any application, report, or document filed pursuant to this [title] . . , which statement was at the time and in the light of the circumstances under which it was made false or misleading with respect to any material fact, shall be liable to any person (not knowing that such statement was false or misleading) who, in reliance upon such statement, shall have purchased or sold a security at a price which was affected by such statement, for damages caused by such reliance, unless the person sued shall prove that he acted in good faith and had no knowledge that such statement was false or misleading.

Securities Exchange Act of $1934 \$ 18,15$ U.S.C. $\$ 78 \mathrm{r}(2000)$. For further discussion of Section 18, see HAZEN, supra note $49, \S 12.18$.

53. Rule $10 \mathrm{~b}-5$ provides that:

It shall be unlawful for any person ...

(a) To employ any device, scheme, or artifice to defraud,

(b) To make any untrue statement of a material fact or to omit to state a material fact necessary in order to make the statements made, in the light of the circumstances under which they were made, not misleading, or 
ployee investors-generally fail employee investors who have been defrauded by misleading employer communications.

Several of these anti-fraud provisions are simply not applicable to misleading employer communications. For example, Section 11 of the ' 33 Act does not reach misleading employer communications because the fraudulent statements to employees would not have appeared in the company's registration statement. Similarly, Section 18 of the ' 34 Act does not help because employer communications are not filed with the SEC. The remaining anti-fraud provisions may reach employer communications, but are inadequate remedies for fraud. For example, Section 12(a)(2) of the ' 33 Act provides only limited relief for misleading employer communications. Because Section 12(a) (2) imposes liability only for misleading statements made in connection with a public offering, ${ }^{54}$ Section 12(a) (2) does not reach misleading employer communications that are made when the company is not making a public offering of securities. That means that most employer communications-those made during the day-to-day operations of a company - will not be subject to the employer liability under Section 12(a) (2).

In addition, Section 17 of the ' 33 Act does not adequately address misleading employer communications. Because most courts have refused to imply a private right of action under Section 17,55 employees who have been defrauded by a misleading employer communication cannot recover under Section 17. The SEC would be able to bring an enforcement action against an employer for a misleading employer communication, but that relief is more illusory than real. For the SEC to be able to bring suit, it would have to be aware of the misleading employer communications. However, as discussed above, employer communications are not disclosed to the public and are not filed with the SEC. ${ }^{56}$ Thus, Section 17 does not provide much help to employees defrauded by misleading employer com-

(c) To engage in any act practice, or course of business which operates or would operate as a fraud or deceit upon any person, in connection with the purchase or sale of any security.

Securities Exchange Act Rule 10b-5, 17 C.F.R. $\$ 240.10 b-5$ (2002). For further discussion of Rule 10b-5, see HAZEN, supra note 49, $\$ 12.4$.

54. See Gustafson v. Alloyd Co., 513 U.S. 561 (1995). In Gustafson, the Supreme Court interpreted "prospectus" as "a term of art referring to a document that describes a public offering of securities by an issuer or controlling shareholder." See id. at 584. Thus, written employer communications are not prospectuses within the meaning of Section 12. For additional discussion of Gustafson, see Hillary A. Sale, Disappearing Without a Trace: Sections 11 and 12(a)(2) of the 1933 Securities Act, 75 Wash. L. REv. 429, 456-61 (2000).

55. See, e.g., Maldonado v. Dominguez, 137 F.3d 1, 7 (1st Cir. 1998) (stating that "[i]n recent years, every circuit to have addressed the issue has refused to recognize a private right of action under Section 17(a), including four circuits which originally had held otherwise").

56. For further discussion of how employer communications are secret, see supra Part IV.A. 
munications, nor does it deter senior managers from making misleading employer communications.

Finally, Rule $10 \mathrm{~b}-5$ provides relief for some misleading employer communications, but allows many-if not most-misleading employer communications to go unremedied. In order to bring suit under Rule $10 \mathrm{~b}-5$, a plaintiff must first meet the standing requirement and have either purchased or sold a security. ${ }^{57}$ Thus, employees who have been fraudulently induced to hold their employer's stock by a misleading employer communication will not be able to recover under Rule $10 \mathrm{~b}-5$. Considering that many employees already own large amounts of employer stock when misleading employer communications are made, ${ }^{58}$ the standing requirement will prevent them from being able to recover a significant portion of their damages when the truth finally is disclosed and the value of their stock plummets. Because senior managers will not be liable for these presumably large damages, Rule 10b-5 fails to adequately deter misleading employer communications. ${ }^{59}$

\section{What Should the Federal Securities Laws Do to Address ThIS VULNERABILITY?}

\section{A. Purchaser/Seller Standing Requirement Should Not Be Changed}

If employees who have been defrauded into holding company securities could sue under Rule 10b-5, companies would certainly be deterred from making misleading employer communications. Thus, one obvious way to address the vulnerability of employee investors would be for courts to create an exception to the standing requirement set forth in Blue Chip Stamps v. Manor Drug Stores ${ }^{60}$ that would permit employees to sue under Rule $10 \mathrm{~b}-5$, even if they have not purchased or sold employer securities. For several reasons, however, I do not advocate the recognition of standing for employees who are fraudulently induced to hold employer securities.

57. This standing requirement was imposed by the Supreme Court in Blue Chip Slamps v. Manor Drug Stores, 421 U.S. 723 (1975). For further discussion of the Blue Chip Stamps standing requirement, see infra Part VI.A.

58. For further discussion of how and why employee stock portfolios are concentrated in employer stock, see supra Part II.B.

59. Arguably, a new white collar crime created by the Sarbanes-Oxley Act of 2002, Pub. L. No. 107-204, 116 Stat. 745 (2002), the first statutory response to the corporate scandals typified by Enron, might deter some misleading employer communications. Section 807 provides that "[w]hoever knowingly executes, or attempts to execute, a scheme or artifice ... to defraud any person in connection with any security of a [reporting company] . . shall be fined under this title, or imprisoned not more than 25 years, or both." See 18 U.S.C.A. $\$ 1348$ (West Supp. 2002). However, any deterrent value will be realized only if the government decides to enforce this section. It remains to be seen whether the enforcement of white collar crime will become a priority of the federal government.

60. 421 U.S. 731 (1975). 
First, it would be extremely difficult for courts to fashion such an exception without violating the Supreme Court's holding in Blue Chip Stamps. Theoretically, I suppose, it could be done. A court could take the position that the holding of Blue Chip Stamps was based in part on an interpretation of the language of Rule $10 \mathrm{~b}-5,{ }^{61}$ but was based predominantly on policy considerations. ${ }^{62}$ Further, upon a close examination of the case, a court could rule that extending standing to employees who were fraudulently induced to hold employer securities would not necessarily frustrate the policy considerations articulated in Blue Chip Stamps. The Supreme Court expressed those policy considerations in a frequently cited part of its opinion, limiting standing to actual purchasers and sellers because "litigation under Rule 10b-5 presents a danger of vexatiousness different in degree and kind from that that accompanies litigation in general." 63 In particular, the Court noted that Rule 10b-5 created a potential for strike suits, primarily due to discovery abuses which encouraged companies to settle even frivolous actions. However, the concern over strike suits has been expressly addressed by Congress in the Private Securities Litigation Re-

61. In Blue Chip Stamps, the Supreme Court reasoned that because the language of Rule $10 \mathrm{~b}-5$ prohibited fraud "in connection with the purchase or sale" of a security, standing should be limited to actual purchasers or sellers. See Blue Chip Stamps, 421 U.S. at 731. The Court also noted that the express private rights of action under the federal securities laws expressly limited standing to actual purchasers or sellers. See id. at 735-36.

The Supreme Court also indicated that it was willing to deny standing under Rule $10 \mathrm{~b}-5$ to holders in part because of the existence of remedies for non-purchasers and non-sellers under state law. See id. at 738 n.9. Employees who have been induced into holding securities by a misleading employer communication may still have a state law remedy, even with the passage of the Securities Litigation Uniform Standards Act of 1998. The Uniform Standards Act preempts most class actions based on misleading statements made "in connection with the purchase or sale" of a security. See Securities Act of $1933 \S 16$ (b), 15 U.S.C. $\$ 77 p(b)$ (2000); Securities Exchange Act of $1934 \$ 28(f)(1), 15$ U.S.C. $\$ 78 b b(f)(1)$ (2000). Courts have interpreted the Uniform Standards Act's "in connection with" requirement to mean that plaintiffs who allege that they were defrauded into holding their securities escape preemption. See, e.g., Green v. Ameritrade, Inc., 279 F.3d 590, 598 (8th Cir. 2002) (holding that "our inquiry leads us inevitably to the conclusion that nonsellers and nonpurchasers of securities are not covered by SLUSA's preemption provision"). But see Joshua D. Ratner, Comment, Stockholders' Holding Claim Class Actions Under State Law After the Uniform Standards Act of 1998, 68 U. CHI. L. Rev. 1035, 1036 (2001) (arguing that state law holding claims are implicitly preempted by the Private Securities Litigation Reform Act of 1995 and Uniform Standards Act). To the extent that employees who have been defrauded into holding employer securities can still sue under state law, the argument for an expanded standing rule is undercut.

62. See Blue Chip Stamps, 421 U.S. at 737-55 (stating that "[i]t is therefore proper that we consider, in addition to the factors already discussed, what may be described as policy considerations when we come to flesh out the portions of the law with respect to which neither the congressional enactment nor the administrative regulations offer conclusive guidance").

63. Id. 
form Act of 1995 (PSLRA) ${ }^{64}$ and the Securities Litigation Uniform Standards Act of $1998,{ }^{65}$ thereby undercutting part of the Court's justification for limiting standing to actual purchasers and sellers.

Moreover, the Court determined that permitting holders to sue under Rule $10 \mathrm{~b}-5$ would also lead to strike suits because it would "throw open to the trier of fact many rather hazy issues of historical fact the proof of which depended almost entirely on oral testimony." 66 In other words, the Court was concerned that a plaintiff who claims he was defrauded into holding a security could get to the jury simply by presenting uncorroborated oral evidence. After the procedural reforms enacted by Congress in the PSLRA, this concern is greatly diminished simply because it is now much more difficult for any plaintiff to get to a jury, even with corroborated evidence. ${ }^{67}$ Finally, the Supreme Court limited standing to actual purchasers and sellers because it recognized that permitting holders of securities to sue would create a huge class of potential plaintiffs, especially since so many Rule $10 \mathrm{~b}-5$ claims arise in anonymous open market trading transactions. ${ }^{68}$ Since a company's employees would constitute a defined-

64. Private Securities Litigation Reform Act of 1995, Pub. L. No. 104-67, 109 Stat. 737 (1998) (codified as amended in scattered sections of 15 U.S.C.). In general, the PSLRA imposed stringent procedural requirements on securities actions brought in federal court, such as a heightened pleading requirement and an automatic stay of discovery upon a motion to dismiss. For an in-depth discussion of the PSLRA, see generally Symposium on the Private Securities Litigation Reform Act of 1995, 51 Bus. LAw. 975 (1996).

65. Securities Litigation Uniform Standards Act of 1998, Pub. L. No. 105-353, 112 Stat. 3227 (1998) (codified as amended in scattered sections of 15 U.S.C.). In the Uniform Act, Congress responded to criticisms that plaintiffs were circumventing the procedural reforms instituted by the PSLRA by filing state securities fraud actions in state court, preempting most class actions based on misleading statements made in connection with the purchase or sale of security. See generally Richard W. Painter, Responding to a False Alarm: Federal Preemption of State Securities Fraud Causes of Action, 84 Cornell L. Rev. 1 (1998); Michael A. Perino, Fraud and Federalism: Preempting Private State Securities Fraud Causes of Action, 50 Stan. L. Rev. 273 (1998).

66. Blue Chip Stamps, 421 U.S. at 743.

67. For example, the PSLRA imposed a heightened pleading requirement which requires that a complaint "shall state with particularity facts giving rise to a strong inference that the defendant acted with the required state of mind." Securities Exchange Act of $1934 \S 21 \mathrm{D}(\mathrm{b})(2), 15$ U.S.C. $\S 78 \mathrm{u}-4$ (b) (2000). For an indepth discussion of the heightened pleading requirement, see generally Hillary A. Sale, Heightened Pleading and Discovery Stays: An Analysis of the Effect of the PSLRA's Intermal-Information Standard on the ' 33 and ' 34 Act Claims, 76 WASH. U. L.Q. 537 (1998).

68. In addition, according to the Supreme Court, the existence of anonymous open market trading in many Rule $10 \mathrm{~b}-5$ actions justified the Blue Chip Stamps standing requirement in another way. The Supreme Court noted that the actual purchaser or seller standing requirement had been abandoned by some state courts, permitting investors who had been defrauded into holding their securities to sue for misrepresentation or deceit under state law. See Blue Chip Stamps, 421 U.S. at 744-46. The Supreme Court distinguished these state cases, noting that the state cases often involved face-to-face transactions. As the Court noted, in the state cases "the plaintiff and the defendant had concededly been engaged in the course 
and limited-class of potential plaintiffs, this concern would be reduced, perhaps justifying an exception to the Blue Chip Stamps standing requirement.

Even if a court were somehow able to create an exception to the actual purchaser or seller standing requirement without violating Blue Chip Stamps, the value of deterring misleading employer communications would be far outweighed by the cost of an expanded standing rule. Specifically, there would be a real concern that companies would decide to curtail communications with their employees, rather than risk opening themselves up to potential liability under Rule 10b-5. Companies would continue to communicate with employees about employment issues, but might decide to reduce, or eliminate, employer communications relating to more general information about the company and its prospects. This would be unfortunate. When complete and accurate, employer communications about the company and its prospects help employees make informed investment decisions about whether or not to purchase employer securities. But an expanded standing rule would probably mean that companies would discontinue making certain types of employer communications, even those that are helpful to an employee's investment decision. Considering that the federal securities laws are grounded on a philosophy of promoting informed investment decisions, ${ }^{69}$ adopting a standing rule that would result in less information reaching employees is troubling.

It is also troubling for another reason, beyond the potential interference with the goals of the federal securities laws. The information contained in employer communications has a significance apart from an employee's investment decision. Employers may want to communicate general information about the company and its prospects for reasons that have nothing to do with encouraging employee investment. For example, the company may want to help employees better understand the company's business, or may want to increase productivity or raise morale. An expanded standing rule might therefore impede a company's ability to conduct its normal business operations. In addition, employees may want to receive employer communications that provide general information about the company and its prospects. After all, many employees expend considerable time, effort, and emotional energy in their jobs. Because they have a vested interest in the success or failure of their employer,

of business dealings with one another, and would presumably have recognized one another on the street had they met." See id. at 745. Thus, the Court recognized that permitting holders to sue in these more personal transactions might make sense, but would not make sense in many Rule $10 \mathrm{~b}-5$ actions, where the company and the investor have no relationship. Since employees do have some sort of relationship to the employer and its management, a court could argue that employees who have been defrauded into holding employer securities should be permitted to bring suit under Rule $10 \mathrm{~b}-5$.

69. See, e.g., Louis Loss \& Joel Seligman, Securities Regulation $\$ 1-G$ (3d ed. 1998) (discussing battle of philosophies that was ultimately won by proponents of disclosure philosophy at expense of "merit" philosophy). 
adopting a standing rule that would deprive them of information about their employer would not be viewed favorably by many employees.

\section{B. Employer Communications Should Be Disclosed to the SEC}

If an expanded standing rule is not the answer to the vulnerability of employees to securities fraud committed by their employer, then what can the federal securities laws do? The answer is, as it often is under the federal securities laws, mandated disclosure. As discussed above, the nonpublic nature of employer communications increases the risk that employer communications will be misleading. ${ }^{70}$ It also decreases the chance that a securities fraud action will be brought for a misleading employer communication. If the problem is the secrecy, then the secrecy should be stopped. If companies were required to disclose employer communications to the SEC, the employer communications would be subjected to critical scrutiny by outsiders. They would also be subjected to a realistic chance of potential liability under Section 17 of the '33 Act and under Rule $10 \mathrm{~b}-5$ of the ' 34 Act, making it less likely that employees will be misled into investing in company stock. Thus, the SEC should promulgate a rule requiring companies to disclose employer communications to the SEC.

Requiring disclosure of employer communications sounds like an easy solution, but, in actuality, it raises a series of complex questions. Which employer communications should be disclosed? How should employer communications be disclosed? Will mandated disclosure of employer communications chill disclosure between the company and its employees? Each of these questions is addressed below.

\section{Which Employer Communications Should Be Disclosed to the SEC?}

Obviously, a company should not be required to disclose all employer communications to the SEC. Employers communicate with their employees on a wide variety of matters, many of which have nothing to do with an employee's decision to invest in company stock. Certainly, the federal securities laws are concerned only with those employer communications that could potentially affect an employee's investment decision. Furthermore, since the concern is that employers may use employer communications to mislead employees into investing in employer stock, the employer communications that should be regulated are those that have the propensity to cause employee investors to hold their employer's stock or purchase additional shares of company stock. Since employers are unlikely to make employer communications that will mislead investors into selling company stock, it does not appear to be necessary to require the disclosure of employer communications that may cause employees to dis-invest in their

70. For discussion of the secret nature of employer communications, see supra Part IV.A. 
company. ${ }^{71}$ In other words, companies should be required to disclose only those employer communications that are reasonably likely to cause employees to purchase company stock or to refrain from selling company stock. ${ }^{72}$

There are several types of employer communications that would meet this standard. For example, employer communications that favorably characterize the company's stock price or future stock price, or that favorably compare the company's stock to other investment opportunities, are the most obvious types of employer communications that would encourage employee investors to purchase or hold additional employer stock. In addition, more general statements that are promotional in nature might also have a propensity to cause employees to hold or purchase company stock. For example, an employer communication that discusses potential growth opportunities might cause employees to decide to invest in employer stock. ${ }^{73}$ Similarly, employer communications denying bad news can also significantly affect an employee's investment decision. That was certainly the case in Enron, where senior management repeatedly urged employees to ignore the reports of accounting irregularities, thereby persuading employees to remain invested in Enron stock. ${ }^{74}$

71. There does not appear to be any good reason to require companies to disclose employer communications that have a propensity to mislead employee investors into selling their company stock. In general, companies desire employee investment. See supra Part II.A. The real concern is that companies make misleading employer communications to encourage-not discourage-employee investment. Therefore, companies are unlikely to issue misleading employer communications that would encourage employees to dis-invest.

72. The "reasonably likely to cause employees to purchase company stock or to refrain from selling company stock" standard bears some resemblance to the definition of materiality set forth by the Supreme Court in TSC Indus., Inc. v. Northway, Inc., 426 U.S. 438 (1976), but it differs in several important respects. First, and most obviously, bad news could constitute material information because there is a "substantial likelihood that a reasonable [investor] would consider [bad news] important in deciding how to [act]." See id. at 449. Because the disclosure of bad news would be reasonably likely to cause employees to sell-not hold or purchase-company stock, employer communications disclosing bad news would not meet the employer communication standard and, therefore, would not have to be disclosed to the SEC. Moreover, in TSC Industries, the Supreme Court made clear that the definition of materiality "does not require proof a substantial likelihood that disclosure of the ... fact would have caused the reasonable investor to change his [decision]." See id. All that TSC Industries requires is that the investor consider the information important. See id. On the other hand, the employer communication standard requires more than a finding that the employee considered the employer communication to be important. It requires a showing that there is a reasonable likelihood that the employee would purchase or hold company stock.

73. For example, Enron management touted several "recent developments" to their employees, including a "billion-dollar contract" with Blockbuster, that was later disclosed to be a failure. See Enron Complaint, supra note 24, II 256-58.

74. For good examples of the misleading statements made by Enron management to employees, see supra notes $35-38$ and accompanying text. 
In addition, a company should be required to disclose to the SEC only those communications that are widely disseminated to all or substantially all of the company's employees. ${ }^{75}$ The intention behind this restriction is to draw a distinction between communications made to employees generally and communications targeted to individual employees or a specific group of employees. Thus, communications made via company-wide emails, newsletters and employee meetings would have to be disclosed, so long as they had a propensity to cause employees to invest in employer stock. On the other hand, a statement made by a CEO during a meeting with a selected group of employees would not have to be disclosed to the SEC, even if the CEO's statement would be likely to cause those employees to purchase or hold company stock. This distinction recognizes that only those employer communications that pose the most danger of defrauding a company's employees should be disclosed. The distinction also recognizes that communications that are not widely disseminated are more likely to have been made in connection with a company's normal business operations, rather than in an attempt to affect the investment decisions of the company's employees. Because employer communications that are widely disseminated to employees are so easy to make and can so easily reach such a large number of potential investors, they ought to be regulated.

In summary, then, the SEC should promulgate a rule requiring reporting companies to disclose all employer communications that (1) are widely disseminated to company employees; and (2) are reasonably likely to cause employees to purchase company stock or to refrain from selling company stock.

\section{How Should the Employer Communications Be Disclosed?}

Employer communications should be publicly disclosed to the SEC so that they can be viewed by journalists, market professionals, attorneys, and other interested investors. But how should public disclosure to the SEC be made? In general, disclosures can be made to the SEC in two different ways: by filing a document with the SEC or by furnishing a document to the SEC. Whether a document must be filed or furnished is important for several reasons. First, Section 18 of the ' 34 Act contains an express private right of action for misleading statements appearing in a document filed with the SEC. ${ }^{76}$ Thus, filed documents are potentially subjected to additional liability under the federal securities laws, while furnished documents are not. Second, filed documents are automatically incorporated by

75. Presumably, employer communications that are widely disseminated to company employees would be made by senior managers of the company. Thus, the kind of communications that an employee would most likely trust and that would be most likely to cause an employee to purchase or hold employer stock would have to be disclosed to the SEC.

76. For the text of Section 18, see supra note 52. 
reference into a company's short form registration statements, ${ }^{77}$ which exposes the company to potential liability under Section 11 of the ' $33 \mathrm{Act}^{78}$ and Section 12(a)(2) of the ' 33 Act. ${ }^{79}$ Thus, if the SEC were to require employers to file communications with the SEC, companies might choose not to make any communications at all, in order to avoid the increased risk of liability under the federal securities laws.

And, in fact, in other contexts, the SEC has recognized that imposing a filing requirement might lead to a significant chilling effect on voluntary company communications and has therefore permitted disclosure to be made by furnishing the information to the SEC. For example, in promulgating the selective disclosure rules under Regulation $\mathrm{FD}^{80}$ - which require companies disclosing material non-public information to certain market professionals to make disclosure to the public as well-the SEC realized that requiring companies to file their informal communications with the SEC could cause companies to limit their disclosures to market professionals. $^{81}$ To prevent this undesirable result, the SEC permitted companies to meet their disclosure requirements under Regulation FD by furnishing the mandated information to the SEC. ${ }^{82}$

The circumstances of selective disclosure are quite similar to employer communications. They both involve a company making a voluntary communication. In other words, the federal securities laws generally do not require a company to disclose information to market professionals or to its employees. Rather, in each case, the company chooses to make these disclosures. In addition, in each case, the voluntary disclosures may promote informed investment decisions. And, assuming the SEC adopts

77. See Registration Statement on Form S-2, Item 12(a) (2) (stating that all reports "filed" under the " 34 Act will be incorporated by reference into the Registration Statement on Form S-2); Registration Statement on Form S-3, Item 12(a) (2) (same).

78. For the text of Section 11, see supra note 49.

79. For the text of Section 12(a)(2), see supra note 50.

80. Regulation FD provides:

Whenever an issuer, or any person acting on its behalf, discloses any material nonpublic information regarding that issuer or its securities to any [market professional], the issuer shall make public disclosure of that information .... :

(1) Simultaneously, in the case of an intentional disclosure; and

(2) Promptly, in the case of a non-intentional disclosure.

See 17 C.F.R. \$ 243.100 (a) (2002).

81. See Selective Disclosure and Insider Trading, Exchange Act Release No. 33-7881, Part II.B.4.a, [2000 Transfer Binder] Fed. Sec. L. Rep. (CCH) If 86,319, at 83,687 (Aug. 15, 2000). Responding to concerns that disclosure of informal communications would be an admission as to the materiality of the communications, the SEC wrote: "In light of these comments, we provide that either filing or furnishing information on Form 8-K to satisfy Regulation FD will not, by itself, be deemed an admission as to the materiality of the information." Id.

82. Regulation FD provides that "an issuer shall make the 'public disclosure' of information required . . . by furnishing to or filing with the Commission a Form 8-K . . . disclosing that information.” See 17 C.F.R. \$ 243.101(e) (2002). 
my proposed rule, in each case, the voluntary disclosures would trigger a mandatory disclosure requirement under the federal securities laws. Thus, the SEC must be careful not to adopt a rule that would discourage companies from making voluntary disclosures. To avoid a potential chilling effect, the SEC should require that companies disclose employer communications by furnishing-rather than filing-the information with the SEC. ${ }^{83}$

\section{Will Mandated Disclosure of Employer Communications Chill Disclosures Between the Company and Its Employees?}

Because employer communications can be beneficial to employees, and because employer communications may be used by a company to conduct its business operations, mandated disclosure should not be adopted if it would chill disclosures from the company to its employees. Requiring a company to furnish its employer communications with the SEC will not have a chilling effect. First, mandating the disclosure of employer communications will not expose companies to an unreasonable risk of litigation under the federal securities laws. As previously demonstrated, limiting standing for violations of Rule $10 \mathrm{~b}-5$ to actual purchasers and sellers $^{84}$ and permitting companies to disclose employer communications by furnishing, rather than filing, the information with the $\mathrm{SEC}^{85}$ substantially alleviates a company's liability concern. If a company makes a misleading employer communication, the company would be subject to an SEC enforcement action and/or a private Rule $10 \mathrm{~b}-5$ action by employees who have purchased company stock. These actions are already available under present law. ${ }^{86}$ Thus, requiring disclosure of employer communications will not create any new liabilities for companies; it will merely create a realistic chance that an action for a violation will be brought.

Moreover, the disclosure requirement should not impose significant out-of-pocket costs on companies. In fact, it would be relatively inexpensive for a company to disclose the most common types of employer communications, those made by e-mail, memorandum, or newsletter. Copies of these documents can simply be forwarded on to the SEC to meet the disclosure requirement. Oral communications made at employee meetings would have to be transcribed so that a written document could be furnished to the SEC, but this would be a minor expense. Similarly, the

83. In addition, the SEC should require that the employer communication be furnished to the SEC within a reasonable time after it was made to the company's employees and must be made accessible through EDGAR, the SEC's Electronic Data Gathering and Retrieval Service.

84. For further discussion of the Rule $10 \mathrm{~b}-5$ standing requirement, see supra Part VI.A.

85. For further discussion of why I recommend the furnishing, and not filing, of employer communications with the SEC, see supra Part VI.B.

86. For a list of actions available under current law, see supra notes 49-53 and accompanying text. 
company would not see an appreciable increase in legal expenses. A company might choose to have counsel review its employer communications before they are transmitted to employees, but this review would not be onerous or overly burdensome. At most, it would resemble the type of review attorneys presently conduct of a company's press releases.

Nor could companies complain that mandated disclosure of employer communications would require companies to disclose confidential information to the public. Because making information widely available decreases the probability that it will remain confidential, it seems unlikely that companies actually disclose any confidential information to their employees through widely disseminated employer communications. Therefore, it seems doubtful that a company could realistically argue that requiring disclosure of employer communications would somehow harm a company's competitive position.

The only real cost associated with the mandated disclosure of employer communications might be that informality is sacrificed. A company might complain that requiring employer communications to be disclosed to the SEC will inject a needless level of formality into its employer communications. In other words, because companies will realize that their communications will be furnished to the SEC, senior management may be forced to watch every word they say to their employees, for fear of future litigation. Actually, this is not a bad result at all. In fact, this kind of disciplining effect is one of the goals of requiring disclosure of employer communications.

\section{Conclusion}

Enron illustrated the kinds of sad stories that can result from misleading employer communications. Specifically, a company can communicate directly with its employees, urging them to invest in company stock. The employees then respond by purchasing additional shares of stock or by holding onto the stock they already own. Then the company publicly discloses information that shows that its employer communications were misleading, and the stock price plunges, causing the employees to suffer substantial losses. Strangely enough, these kinds of employer communications-although they clearly affect the investment decisions of company employees-are left largely unregulated by the federal securities laws. Considering the significance of employee investment in companies, and the particular vulnerability of employees to securities fraud committed by their employer, this is a shocking regulatory gap. To fill this gap, the SEC should promulgate a rule requiring reporting companies to disclose all employer communications that are widely disseminated to company employees and that are reasonably likely to cause employees to purchase company stock or to refrain from selling company stock. Requiring disclosure of employer communications would have a disciplining effect on senior management without chilling the disclosure of information by 
O'H are: M isleading Employer Communications and the Securities Fraud Impli

2003] Misleading Employer Communications

1243

employers to their employees. Although modest in scope, such a rule would help ensure that there are no sequels to the sad stories told by Enron employees. 
Villanova Law Review, Vol. 48, Iss. 4 [2003], Art. 9 